I N T ER N ATIONAL MONETARY FUND

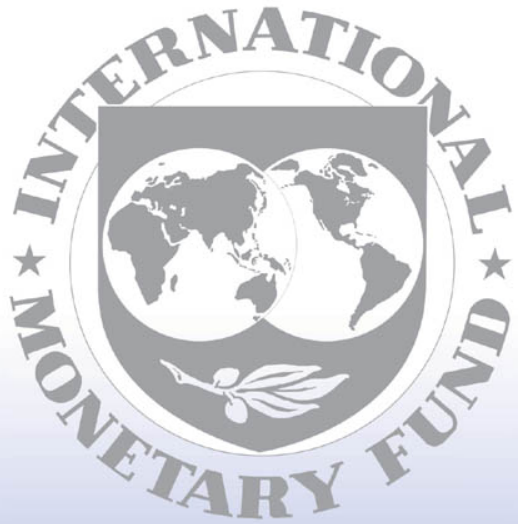

Staff

Country

Reports 


\section{Mongolia: Ex Post Evaluation of Exceptional Access Under the 2009 Stand-By Arrangement}

This Ex Post Evaluation of Exceptional Access Under the 2009 Stand-By Arrangement on Mongolia was prepared by a staff team of the International Monetary Fund as background documentation for the periodic consultation with the member country. It is based on the information available at the time it was completed on February 24, 2011. The views expressed in this document are those of the staff team and do not necessarily reflect the views of the government of Mongolia or the Executive Board of the IMF.

The policy of publication of staff reports and other documents by the IMF allows for the deletion of market-sensitive information.

Copies of this report are available to the public from

International Monetary Fund $\bullet$ Publication Services

$70019^{\text {th }}$ Street, N.W. • Washington, D.C. 20431

Telephone: (202) 623-7430 • Telefax: (202) 623-7201

E-mail: publications@imf.org Internet: http://www.imf.org

\section{International Monetary Fund Washington, D.C.}


INTERNATIONAL MONETARY FUND

MONGOLIA

\title{
Ex Post Evaluation of Exceptional Access Under the 2009 Stand-By Arrangement
}

\author{
Prepared by a Staff Team from APD, FAD, RES, and SPR ${ }^{1}$ \\ Authorized for Distribution by the Asia Pacific \\ and Strategy, Policy, and Review Departments
}

February 24, 2011

Contents

I. Introduction and Summary $\underline{3}$

II. Overview - Cause and Resolution of the Crisis............................................................ 4

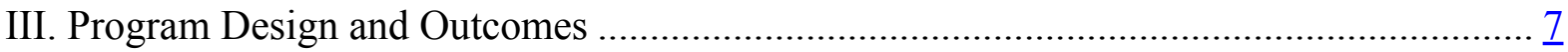

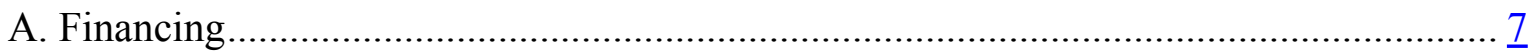

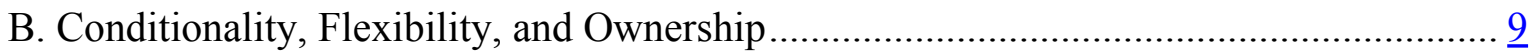

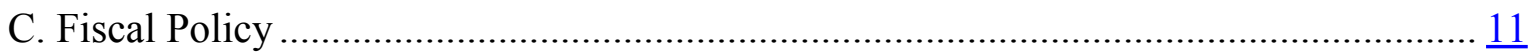

D. Monetary Policy and Foreign Exchange Market …………….............................. $\frac{15}{16}$

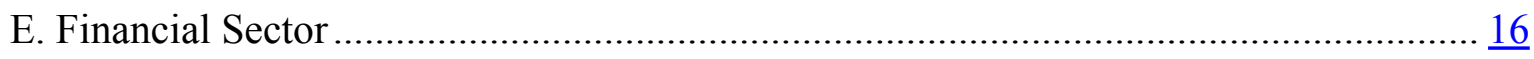

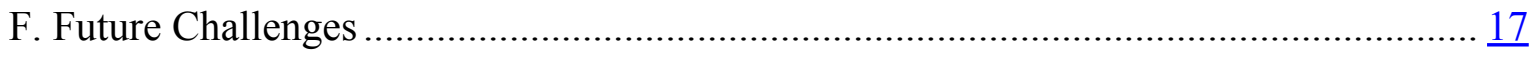

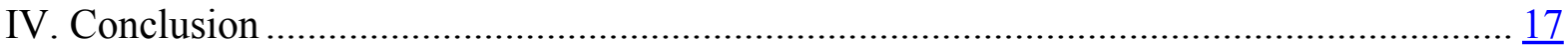

Boxes

1. Exceptional Access Criteria...............................................................

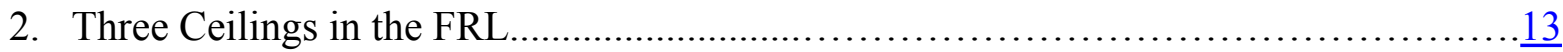

Tables

1. Progress with Structural Benchmarks............................................ 19

2. Performance Criteria: Targets and Outcomes.....................................

\footnotetext{
${ }^{1}$ The team comprised Jaewoo Lee (head, RES), Yanliang Miao (SPR), Yasuhisa Ojima (APD), and Seok Gil Park (FAD). In accordance with Fund procedures, this report was prepared at headquarters by an interdepartmental staff team, primarily on the basis of available documents and data. The team is grateful for conversations with former mission chiefs and other staff who were involved. The draft report has been discussed with the authorities during a staff visit on Feb 8-10, 2011, and their largely factual comments have been incorporated in the finalized report. The authorities were in broad agreement with the report and chose not to provide a section to summarize their reactions.
} 
Figures

1. Macroeconomic Developments..................................................

2. Comparison of Macroeconomic Performance with Other Program Countries................... 22

3. Program Projections, Targets, and Outcomes....................................... 


\section{INTRODUCTION AND SUMMARY}

\section{Mongolia was extended an 18-month Stand-By Arrangement (SBA) in April} 2009. To help economic adjustment in the midst of the global financial crisis, the program was supported by Fund resources amounting to 300 percent of quota (SDR 153.3 million), with more than 200 percent of quota to be made available within the year under the exceptional access policy. The program was concluded in September 2010 after its full term, bringing the Mongolian economy a step closer to vibrant economic development.

2. This ex-post evaluation assesses the conception and achievement of the $\mathbf{2 0 0 9}$ program with Mongolia. Following this introductory section, Section II discusses the cause of Mongolia's crisis in 2008-09 and its resolution under the program. Section III discusses in greater detail the design and outcomes of the program. Section IV concludes.

3. In a nutshell, the 2009-10 program for Mongolia - the first Fund SBA in Asia after the Asian financial crisis-was a success, despite lingering uncertainty on its legacy. The Mongolian economy had been hit hard by the global financial crisis through a sharp drop in the price of its main export commodities. The program helped cushion the adverse consequence of the shock by combining strong policy adjustments and the frontloaded financing of an exceptional size, which in turn catalyzed donor financing. The program also facilitated significant structural reforms which should strengthen the resilience of the economy against future shocks. Nevertheless, concerns remain on the post-program outcomes: uncertainty is shrouding the prospects for implementing reforms initiated under the program.

4. Several lessons can be drawn from the experience of the program.

- $\quad$ Set streamlined and focused conditions in key areas of Fund's core expertise and essential to program objectives. The light conditionality facilitated both the program negotiation and its subsequent implementation despite some unexpected developments in the global economic environment.

- $\quad$ Demonstrate flexibility in dealing with changing economic and political circumstances, while remaining focused on core policy measures. Such principled flexibility helped enhance ownership, aided by extensive outreach for main stake holders and opinion leaders.

- $\quad$ Provide timely technical assistance (TA) which facilitates the implementation of program measures. Significant and timely TAs were instrumental for putting several program agreements into practice.

- $\quad$ Explore ways to secure a lasting commitment to implement and sustain progresses made under the program. Concerns on the follow-up implementation have clouded the legacy of the otherwise successfully concluded program. 


\section{OVERVIEW-CAUSE AND RESOlution OF THE CRISIS}

5. The trigger for Mongolia's crisis in 2008-09 was the collapse in the prices of its commodity exports, copper in particular. In the midst of the global financial crisis, the price of copper-Mongolia's primary exports - declined by 70 percent after reaching the peak level in July 2008 at the heel of the global commodity boom. Copper production played a prominent role in Mongolia's economy, having contributed more than half of merchandise exports and about a quarter of government revenues in recent years. The resulting decline in exports and the government's mineral revenues weighed heavily on the economy and opened up large deficits on both fiscal and external accounts, heightening the risk of a disruptive contraction in

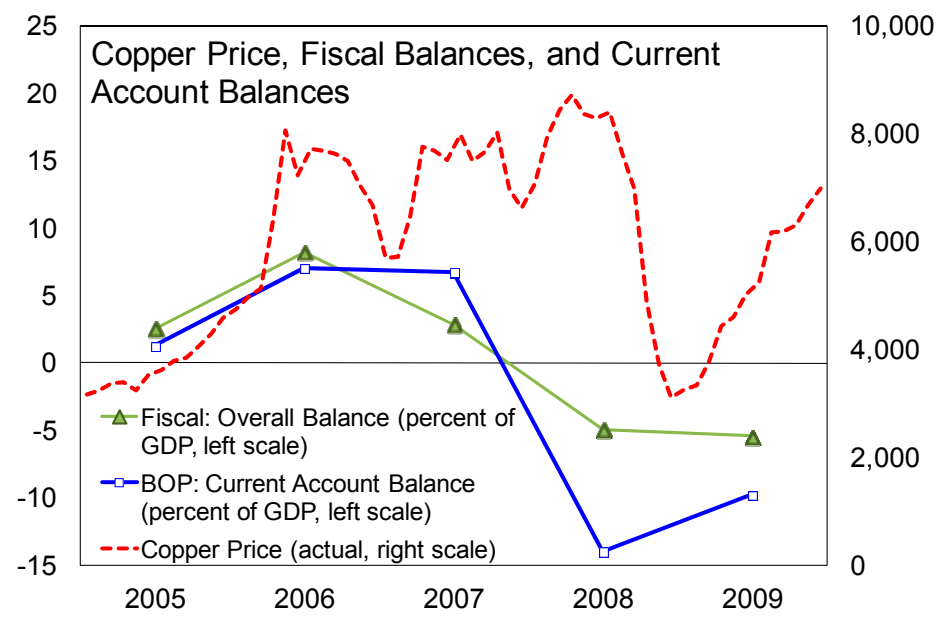
economic activity.

\section{The macroeconomic policy framework was not robust enough to withstand an} external shock of this magnitude. Government expenditure had expanded with the rise in mineral revenues, pushing the non-mineral deficit to near 10 percent of GDP in 2007 without a ready replacement in the event of a shortfall in mineral revenues. Monetary policy had been accommodative, with the inflation rate reaching double digits by late 2007 and the real interest rate falling to the negative range. Following a double-digit growth in credit over the same period, the banking sector got over-extended. Under the adverse economic condition, the weakness in bank balance sheets surfaced and the ratio of non-performing loans began to rise. Economic prospects weakened rapidly, with GDP growth being projected to decline to some $2 \frac{1}{2}$ percent for 2009 from the average 9 percent over the 2006-08 period. Capital outflows rose and, combined with a tightly controlled exchange rate, led to the decline in the stock of international reserves.

\section{Despite several initial policy adjustments, pressure on the balance of payments} kept mounting and the risk of further outflows from the domestic financial system was on the rise. Although the Bank of Mongolia allowed the exchange rate to depreciate since November 2008 and began to ration foreign currencies for essential imports, the foreign exchange reserves declined steadily_by end-February 2009, the net reserves fell to US\$ 500 million, more than halving from the peak level in mid-2008. The confidence in the banking sector wavered, deposits were withdrawn from the banking system, and remaining deposits were being shifted to foreign exchange deposits, all despite the blanket deposit guarantee introduced after an isolated run on the fourth largest bank (Anod bank) in December 2008. 
Weak economic prospects and a gaping hole in the government budget continued to chip away confidence in the economy and government policies (including deposit guarantees). The drain on the foreign exchange reserves and banking system was showing signs of accelerating by early March, and the danger was building that a self-fulfilling run on foreign exchange reserves and banking system could be instigated by some unexpected event. ${ }^{2}$

8. The Fund-supported SBA was agreed at the staff level in March 2009, to restore economic stability and support policy adjustment. Four key planks of the program were: restoring health to government finances; allowing the exchange rate to adjust flexibly while safeguarding international reserves; bolstering confidence in the banking system; and protecting the poor during the adjustment. The program combined a significant fiscal adjustment and a large financing to avert an impending fiscal, banking, and balance of payments crisis. To restore confidence in the economy domestically and internationally, the disbursement of funds was front loaded - making a half available within the first six months. In order to strengthen the institutional framework and reduce future vulnerability, the program included structural reform measures to reduce the pro-cyclicality of budget, to improve social transfer

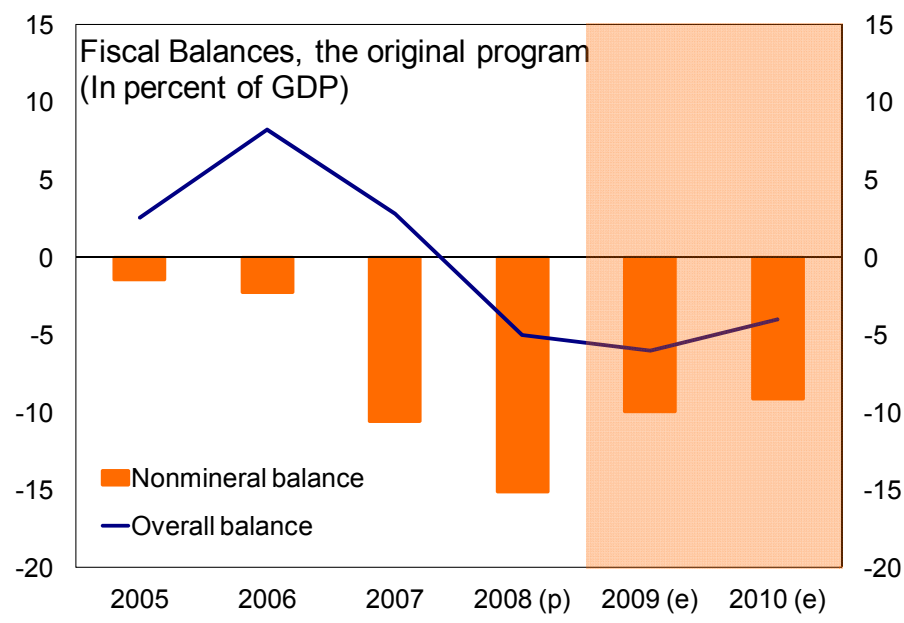
programs, and to enhance bank supervision.

9. The IMF program helped restore macroeconomic stability, including by stabilizing the foreign exchange market and catalyzing further external financing. The precipitous exchange rate depreciation stopped, as the central bank raised sharply the policy interest rate and successfully implemented twice-weekly auctions of foreign exchanges, against the backdrop of the program financing. The parallel foreign exchange rate peaked in mid-March, and the central

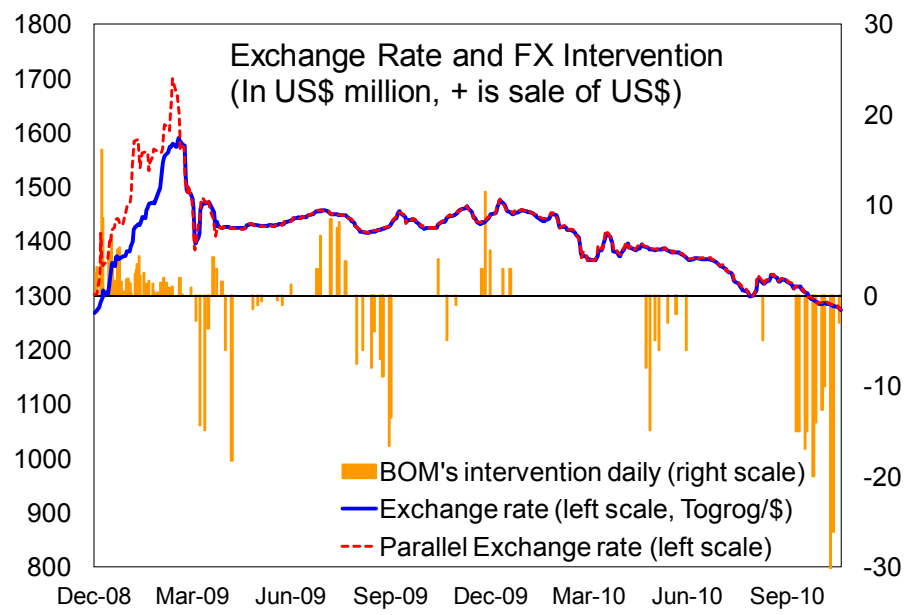

\footnotetext{
${ }^{2}$ On the role of domestic capital outflows (financed by withdrawals from bank deposits) in triggering a BOP crisis, see "Financial Stability, the Trilemma, and International Reserves," (Maurice Obstfeld with Jay C. Shambaugh and Alan M. Taylor, American Economic Journal 2010).
} 
bank's sale of foreign exchanges turned to net purchase in March 2009 for the first time since late-2008. Donor financing arrived to fill the gap in government finance, bolstering confidence in the banking sector backed by deposit guarantees of the government.

\section{The strong policy adjustment under the program maintained the} macroeconomic stability and steered the economy through the turning point. The authorities succeeded in restraining expenditure to keep the overall deficit within program targets, despite the more-than-expected weakness in government revenues and the economy during the early phase of the program. The central bank could begin to lower the policy interest rate in May, as the inflation rate fell and the exchange rate stabilized, and kept rebuilding its stock of international reserves opportunistically. The authorities appointed receivers for problem banks in late 2009, which reduced the stress in the banking system.

\section{The economy bottomed out and growth resumed in late 2009, as the effect of} copper price rebound filtered through the economy (Figure 1). Even though the copper price began to rise in mid-2009, the economy continued to weaken, leaving the government finance and the banking sector under strain for most of the year. The delay in economic recovery was partly due to the usual lag with the effects of commodity price changes and partly due to the delay in the mining development contract. ${ }^{3}$ Since late 2009, economic growth resumed and government revenues rose above the level expected at the program inception. On the back of a stronger-than-expected recovery, the macroeconomic policy discussion in 2010 focused on efforts to head off overheating. Government expenditure and non-mineral deficit also rose above the original program projections, but keeping the overall balance within the program target. Bank balance sheets improved and the system-wide ratio of non-performing loans declined, albeit with a substantial variation among individual banks.

\section{The program improved the policy mixture and paved the way for better} responses to future shocks, though without a proactive assurance of post-program implementation. Key fiscal structural benchmarks facilitated the submission and passage of the Fiscal Responsibility Law (FRL), albeit with modest delays and lingering uncertainties on its full implementation. Monetary and exchange rate policy was recalibrated to safeguard international reserves, ensure the market-based floating of the exchange rate, and keep inflation on a downward path. Legislative progress was made with the framework for bank supervision and restructuring, though with lesser progress in implementation. Failing to achieve the desired adoption of a targeted poverty benefit, the program made the least progress in welfare reform. The social transfer reform law was still under parliamentary deliberation at program conclusion, while the authorities had substantially increased untargeted social transfers which benefited the poor despite their high inefficiency.

\footnotetext{
${ }^{3}$ The Oyu Tolgoi mining project was finalized in October 2009 with the participation of a joint venture between Ivanhoe Mines Ltd (Canada) and Rio Tinto PLC (United Kingdom).
} 
13. The program was concluded successfully, having averted a full-blown crisis and laid the foundation for further strengthening macroeconomic and financial policy framework (Figure 2). In October 2010, the real GDP growth was projected to exceed 8 percent in 2010 and international reserves stood at the historical high (US\$ 1.6 billion). The economic outlook in the coming years remains strong, largely on the strength of the mining sector where several major projects were set in motion. The future challenge lies in building up on the momentum for policy reform, to limit pro-cyclicality of macroeconomic policies, and to eventually reinforce the resilience of the economy against unavoidable swings in world commodity prices. However, developments since the conclusion of the program began to cloud the prospects for a steadfast improvement in policy framework.

Table. Program Chronology

\begin{tabular}{llll}
\hline & \multicolumn{2}{l}{ Amount of Purchase } & \\
\cline { 2 - 3 } Date & $\begin{array}{l}\text { In percent of } \\
\text { quota }\end{array}$ & In SDRs & Condition \\
\hline April 1, 2009 & 100 & $51,100,000$ & Approved Stand-by Arrangement. \\
June 23, 2009 & 50 & $25,550,000$ & Completion of the first review \\
September 21, 2009 & 30 & $15,330,000$ & Completion of the second review \\
December 22, 2009 & 30 & $15,330,000$ & Completion of the third review \\
March 19, 2010 & 30 & $15,330,000$ & Completion of the fourth review \\
September 8, 2010 & 60 & $30,660,000$ & Completion of the fifth and sixth review \\
Total & 300 & $153,300,000$ & \\
\hline
\end{tabular}

\section{Program Design And Outcomes}

\section{A. Financing}

14. The high access to Fund resources under the 2009-10 SBA-SDR 153.3 million, 300 percent of quota in total, and 240 percent of quota within 12 months - was deliberately chosen to shore up the faltering confidence in the currency and dwindling reserves. The currency depreciated over 30 percent between November 2008, the time when a Fundsupported program was requested, and early March 2009 when staff level agreement was reached. Foreign reserves declined by roughly US\$ 100 million per month. The proposed access was doubled from the originally discussed 150 percent of quota given the worsening outlook for capital account flows and increasing prospects for resident outflows from the banking system. The front-loaded phasing of access enhanced the credibility of the program by addressing the urgency and likely short duration of the balance of payments need. 


\section{The Fund took a calculated risk in approving an SBA with exceptional access to}

a PRGF-eligible country. While the four criteria for exceptional access (Box 1) were met, significant uncertainties and risks remained at the time of program approval. The first criterion was clearly satisfied given the severity and the imminence of a full-blown BOP crisis. The second criterion was also met, taking into account the relatively low level of public debt to start with and the proposed ceilings of non-concessional external borrowing. ${ }^{4}$ Since Mongolia had only limited access to private capital markets, the assessment on the third criterion was based on the strong prospects of FDI inflows. The most uncertain and debatable was the satisfaction of the fourth criterion that "the policy program of the member country provides a reasonably strong prospect of success." None of Mongolia's four previous programs with the Fund were successfully completed and the most recent one, the 2001 three-year arrangement under the PRGF, did not go beyond the second review. The lack of a track record of program implementation and the potential loss of ownership due to upcoming presidential elections in May 2009 clouded the prospects for a successful SBA.

\section{Box 1. Exceptional Access Criteria}

Criterion I: The member is experiencing or has the potential to experience exceptional balance of payments pressures on the current account or the capital account, resulting in a need for Fund financing that cannot be met within the normal limits.

Criterion II: A rigorous and systematic analysis indicates that there is a high probability that public debt will remain sustainable in the medium term. However, in instances where there are significant uncertainties that make it difficult to state categorically that there is a high probability that the debt is sustainable over this period, exceptional access would be justified if there is a high risk of international systemic spillovers.

Criterion III: The member has good prospects of gaining or regaining access to private capital markets within the timeframe when Fund resources are outstanding.

Criterion IV: The policy program of the member country provides a reasonably strong prospect of success, including not only the member's adjustment plans but also its institutional and political capacity to deliver that adjustment.

\section{However, the prospect of success was sufficiently strengthened by a careful risk} management which included the front-loading of significant policy measures. In particular, a significant and challenging fiscal adjustment was adopted upfront in the amended 2009 budget and non-discriminatory foreign exchange auctions were implemented ahead of the program approval. To ensure debt sustainability, ceilings were imposed on contracting non-concessional external debt as a performance criterion. The authorities made it clear that they would return to parliament for additional expenditure measures in the event of a further revenue shortfall.

\footnotetext{
${ }^{4}$ The benign outlook and low risk of debt distress from staff's Debt Sustainability Analysis (DSA) would not have been possible, had it not been for the significant reduction of debt from 87 to 33 percent of GDP between 2003 and 2008. See IMF CR 09/130 and 10/166.
} 
Table. Prior Actions

The passage by the parliament of the 2009 budget amendment consistent with program targets.

Appointment of a reputable external auditor to make diagnostic assessment on the portfolio and offbalance sheet transaction of Anod Bank.

Revision and clarification of blanket deposit guarantee by including current accounts as well as savings accounts, time deposits and interbank deposits; and by excluding all deposits of related persons to the bank as defined in the banking law, and deposits of holders of subordinated debt.

Establishment of a foreign currency auction mechanism at the Bank of Mongolia (a structural benchmark completed by April 1, 2009).

17. The program succeeded in catalyzing funds from other sources. Despite the augmented access, there was still an estimated financing need of about US\$ 200 million (US\$ 144 million in 2009 and US\$ 60 million in 2010) to be funded by bilateral donors and other international financial institutions. The Asian Development Bank, the World Bank, and Japan International Cooperation Agency (JICA) together pledged US\$ 160 million, filling in the bulk of the remaining financing gap, at a donor conference that immediately followed the staff-level agreement on the SBA. The successful conference also benefited from the close involvement of the Fund management in persuading donors. The Fund commitment — up to US\$ 232 million - was 53 percent of the estimated total financing need of US\$ 437 million, close to the average of the Fund's share of financing packages (56 percent) in the global financial crisis but considerably higher than that in past crises (40 percent).

\section{The SBA was a preferred arrangement, befitting the exigent financing need and} more agreeable to the authorities than other available facilities. The Fund offered in early 2010 an arrangement under the PRGF with more concessional financing and lower access as a possible exit strategy, but the authorities were not interested for they were planning to access international financial markets in the near future. Mongolia's financing need turned out to be indeed temporary with the quick rebound of copper price and the contracting of a large mining project. The Fund then had also in place the Exogenous Shocks Facility with a high access component (ESF-HAC, later superseded by the Standby Credit Facility). But the large BOP need was also due to domestic policy slippages underlined by broad structural problems, which made the ESF an inappropriate alternative.

\section{B. Conditionality, Flexibility, and Ownership}

\section{Program conditions were streamlined, with fiscal reforms looming prominently} among structural benchmarks. There were seven performance criteria (PCs) including on net international reserves (NIR), net domestic assets (NDA), net bank credit to government, and non-concessional external debt. Fiscal deficit ceiling was established as an indicative target, rather than a PC, reflecting substantial uncertainties facing the Mongolia economy and 
given the PC on net credit to government. The coverage of these quantitative targets was comparable to previous Fund arrangements with Mongolia and contemporaneous SBAs after the breakout of the global financial crisis. The number and breadth of structural benchmarks, however, was significantly fewer and much more focused than in previous arrangements (Table 1). ${ }^{5}$ Five of eight structural benchmarks were on fiscal reforms, reflecting the primacy of fiscal pro-cyclicality in leading to the crisis. Two structural benchmarks applied to the banking sector, given that banking problems were a secondary contributor to the crisis. And all targets and benchmarks were well aligned with the Fund's core expertise and essential to program objectives.

\section{The program was predicated on assumptions of rather persistent weakness in} global copper price and investment inflows, which underestimated the quick and strong rebound of copper price. Copper price continued its strong recovery since mid-2009, leaving the 2009 annual average nearly 50 percent higher than the US\$3500 projected in the program (Figure 3). Nor did the program assume that significant investment inflows to the Oyu Tolgoi mine would start as early as late 2009. The rather conservative macroeconomic framework, however, appears to have strengthened the program by avoiding large surprises between fiscal targets and outturns. Elsewhere and around the same time, less conservative macroeconomic framework led to large fiscal slippage which contributed to program going off track. ${ }^{6}$

\section{Evolving circumstance was met with a flexible adaptation throughout the}

program. During the program negotiation stage, on-lending operations by the government to gold mining companies were allowed despite the risk that it might trigger the PC on NDA of the Bank of Mongolia. In successive program reviews, the quantitative PCs were adjusted in line with economic developments, and the structural benchmarks were rescheduled multiple times to allow a political gestation period (Tables 1 and 2). The flexibility was also exercised to urge action: the Fund delayed the completion of the fifth review until tangible progress was made on fiscal structural reforms and on expenditure restraint in the upcoming budget.

\section{The provision of timely TA was instrumental to moving the program forward.}

Many structural benchmarks were implemented with the assistance of TAs from FAD and MCM - between November 2008 and October 2010, about 20 TAs were provided by the Fund, enabling the program to make a solid, if not always smooth, advance. In particular, MCM provided intensive TAs during the early phase of the program, including on the foreign exchange auction (a prior action) in March 2009, followed closely by those on monetary policy, bank supervision and restructuring.

\footnotetext{
${ }^{5}$ For a detailed list of structural benchmarks contained in previous arrangements, see "Mongolia—Ex Post Assessment of Longer-term Program Engagement," International Monetary Fund, 2005 (SM/05/344).

${ }^{6}$ See "El Salvador: Ex Post Evaluation of Exceptional Access under the 2009 Stand-By Arrangement," International Monetary Fund, 2010 (CR/10/303).
} 


\section{The streamlined and flexible conditionality facilitated negotiation and} strengthened ownership of the program, beyond the experience of previous Mongolian engagements with the Fund. During the program negotiation, the parsimonious design helped the discussion move beyond the memory of past program conditions, some of which the authorities had deemed too onerous to implement timely. Once agreed, commitment to the program was sustained through the end despite some ebbing and flowing, in contrast to previous arrangements which were invariably led off track by flagging commitment. By early 2010, it became clear that there was no need to tap the remaining SDR 30.66 million tied to the completion of the last two quarterly reviews. The authorities, however, pressed ahead with difficult structural reforms despite the change of leadership at the highest level and the disappearing financing need. ${ }^{7}$ The ownership was also enhanced by extensive outreach, including regular meetings with the speaker of parliament and key committee chairs. The Fund staff also delivered parliamentary workshops on topical issues such as inflation and the FRL.

\section{Fiscal Policy}

\section{The centerpiece of fiscal adjustment was a significant reduction in the overall}

balance deficit. A fiscal adjustment would reduce the financing gap and help move the fiscal deficit toward a sustainable range. The indicative target for the 2009 fiscal deficit was set at 6 percent of GDP, which involved reducing the non-mineral deficit by more than 5 percentage points of GDP from the 2008 outturn. The target was set in terms of the overall balance leaving room for fine-tuning to future developments and for the authorities' discretion in choosing the details of fiscal adjustment that would deliver the targeted balance. This was another facet of light conditionality of the program, which helped strengthen the program ownership of the authorities, though possibly at the cost of imposing a weak restraint on expenditure growth in the event of revenue over-performance. More emphasis could have been placed on the underlying fiscal effort by setting quantitative PCs on the primary deficit or non-mineral deficit. However in early 2009, the Fund and the world were more concerned - rightfully — with downside risks. ${ }^{8}$ In the event of a significant revenue shortfall, overall deficit target would have helped limit the financing need.

\section{Because of large uncertainty during the global crisis, the balance between adjustment and financing continuously shifted in response to changing copper prices} and growth prospects. The macroeconomic implication of fiscal policy is thus appraised in light of the evolving tradeoff among competing objectives. The first main development was a further weakening in the economy in mid-2009. The second and more significant development was the faster and stronger-than-expected recovery in mineral prices and the

\footnotetext{
${ }^{7}$ The last two reviews were concluded without disbursement of funds.

${ }^{8}$ The World Economic Outlook (April 2009) projected world output to decline by 1.3 percent in 2009, which in the event contracted by 0.6 percent.
} 
contracting of a large copper mine in late 2009. This greatly strengthened the outlook for the economy and government revenues, with double-digit real GDP growth being projected for several years from 2013.

\section{Fiscal targets were satisfied with a comfortable margin in most reviews, initially owing to disciplined spending and later thanks to the strong recovery in copper price.} For most of the 2009, the authorities maintained a solid restraint on expenditure, despite the weaker-than-expected economy and revenue which led to a slight easing of the deficit target in mid-2009. Capital expenditures were postponed, and wages and other current expenditures were restrained, while making commitment to a future overhaul of social transfer regime in a structural benchmark. With the rebound in the economy and mineral revenues since late 2009, the deficit targets were appropriately revised down to smaller deficits in several successive reviews while the fiscal expenditures were being increased to provide further support to the economy under a somewhat reduced financing need. The 2010 budget deficit target was revised eventually to $2 \frac{1}{4}$ percent of GDP — nearly half the initial program level for 2010 .

Table. Developments in fiscal projections for 2009 and 2010 (in percent of GDP)

\begin{tabular}{|c|c|c|c|c|c|c|c|c|c|}
\hline & \multicolumn{4}{|c|}{2009} & \multicolumn{5}{|c|}{2010} \\
\hline & $1 \mathrm{st}$ & 2nd & $3 \mathrm{rd}$ & Act & $1 \mathrm{st}$ & 2nd & 3rd & 4th & 6th \\
\hline Total revenue and grants & 30.8 & 30.8 & 30.7 & 32.9 & 31.6 & 30.1 & 33.0 & 34.5 & 34.9 \\
\hline Total expenditure and net lending & 36.8 & 37.3 & 37.2 & 38.3 & 35.6 & 35.0 & 38.0 & 38.5 & 37.1 \\
\hline Current expenditure & 28.5 & 29.4 & 28.5 & 29.6 & 26.7 & 27.2 & 30.3 & 30.8 & 29.6 \\
\hline Capital expenditure and net lending & 8.3 & 7.9 & 8.7 & 8.7 & 8.9 & 7.8 & 7.7 & 7.7 & 7.5 \\
\hline Overall balance, projected and actual & -6.0 & -6.5 & -6.5 & -5.4 & -4.0 & -5.0 & -5.0 & -4.0 & -2.2 \\
\hline Nonmineral overall balance & -9.9 & -12.1 & -12.7 & -12.9 & -9.1 & -9.0 & -12.2 & -12.2 & -11.2 \\
\hline Structural balance & $\ldots$ & $\ldots$ & -5.0 & -7.6 & $\ldots$ & $\ldots$ & -5.1 & -4.2 & -5.6 \\
\hline \multicolumn{10}{|l|}{ Memorandum items: } \\
\hline Nominal GDP (in billions of togrogs) & 6,294 & 6,209 & 6,407 & 6,056 & 7,180 & 6,931 & 7,373 & 7,221 & 7,911 \\
\hline Real GDP growth rate & 2.7 & 0.5 & -1.0 & -1.6 & 4.3 & 3.0 & 8.6 & 7.3 & 8.5 \\
\hline Copper price assumption (US\$ per ton) & 3,500 & 4,000 & 5,000 & 5,165 & 3,800 & 4,100 & 5,800 & 6,500 & 6,911 \\
\hline
\end{tabular}

\section{Fiscal recalibration softened the exigent adjustment that had been demanded in} the original program, but at the cost of a rather tepid reduction in the pro-cyclicality of budgeting. The 2009 outturn of non-mineral balance deficit exceeded the initial program projection by 3 percentage points of GDP, implying a greater reliance on cyclical mineral revenues than had been envisaged. Compared to the 2008 outturn, the 2009 non-mineral deficit declined by about 2 percentage points of GDP, thus by about half the magnitude of fiscal adjustment targeted in the original program (at the peak of financing pressure). This helped smooth economic adjustment by capitalizing on the relaxed financing need, but limited the progress in reducing fiscal pro-cyclicality. The structural deficit-introduced afterwards in the FRL — provides an instructive gauge of fiscal pro-cyclicality, by calculating revenues on the basis of 16-year moving average of mineral prices. In the 2009 outturn, structural deficit exceeded the $3^{\text {rd }}$-review projection by $2 \frac{1}{2}$ percentage points of GDP, 
implying that the expenditure grew faster than the long-term trend in mineral prices. In the tradeoff between providing a greater short-term stimulus and pre-emptively reducing fiscal pro-cyclicality, more weight was placed on providing short-term stimulus. A similar policy preference was revealed in successive revisions of fiscal targets for 2010, contributing to the quick and strong recovery.

\section{The legislation of Fiscal}

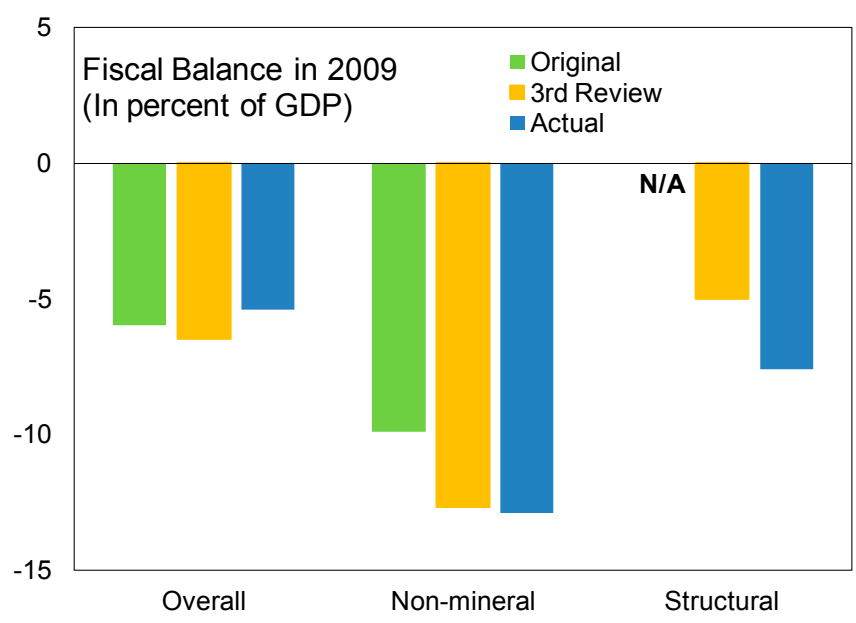

\section{Responsibility Law (FRL) was a} milestone in tackling the pro-cyclical policies at the root of the crisis. In an effort to rally the political support, the legislation was delayed to June 2010 from the original deadline of December 2009. By 2013, the FRL would put in place three complementary ceilings on structural deficit, total debt, and expenditure growth that would work together to ensure fiscal discipline (Box 2). ${ }^{9}$ The two-thirds majority required on any attempt to amend this law signaled strong ownership of the program and the authorities' success in garnering political support for fiscal discipline. The FAD TA was instrumental in the development of the FRL, as well as in ongoing assistance in other areas of fiscal policy.

\section{Box 2: Three Ceilings in the FRL}

- $\quad$ The floor of structural balance is the deficit of 2 percent of GDP. The structural balance is calculated by using the moving average price of major minerals—currently copper and coal—over 16 years (past 12 years, current year, and future three years). This provision takes effect in 2013.

- $\quad$ The ceiling of expenditure growth is the non-mineral GDP growth rate, determined as the greater between its 12-year moving average value and the budget year's GDP growth rate. This provision takes effect in 2013.

- $\quad$ Net present value of public debt cannot exceed 40 percent of GDP. This provision takes effect from 2014 , and the government can make loan guarantees for a development bank by 10 and 20 percent of GDP (net present value) in 2011 and 2012, respectively.

\footnotetext{
${ }^{9}$ This is comparable to the use of structural balance based on average copper prices in Chile (IMF OP 231, Chile: Institutions and Policies Underpinning Stability and Growth, 2004). Eventually, savings fund can reinforce fiscal stability (IMF OP 205, Stabilization and Savings Funds for Nonrenewable Resources: Experience and Fiscal Policy Implications, 2001) and external stability (IMF WP 09/33, Current Account and Precautionary Savings for Exporters of Exhaustible Resources, by Rudolfs Bems and Irineu de Carvalho Filho). In the event, Stabilization Fund will be formed effective fiscal year 2011 to create a buffer for potential revenue shortfalls in the future, as the budget has become increasingly dependent on mining revenues.
} 


\section{However, significant concerns remain on the full implementation of the FRL.}

During the legislation process, the implementation of some FRL provisions-including the floor of structural balance - was delayed from the 2011 budget to the 2013 budget, with no provisions for transitional deficit targets in intervening years. This change was a political cost

of parliamentary approval and had a discouraging consequence. Whereas the FAD TA had recommended the transitional structural deficit targets of 4 and 3 percent for 2011 and 2012, respectively, the 2011 budget - finalized after the programenvisaged a structural deficit of nearly 10 percent of GDP, putting in a road block for a full implementation of the 2 percent structural deficit target in 2013. A stronger commitment to the FRL implementation could not be secured, for the legislation of

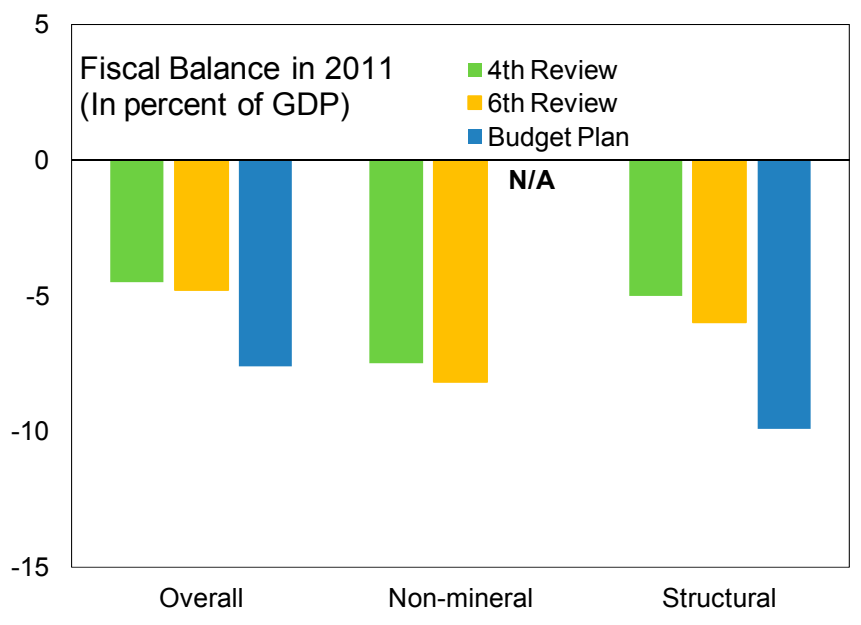
the FRL all but consumed the Fund's bargaining power that inevitably shrank when commodity prices and economic growth staged a strong rebound. ${ }^{10}$

\section{Progress was slower with social transfer reform, the other key fiscal reform to} accompany the FRL. Given that one-third of population was below the poverty line, the initial plan was to legislate by November 2009, consolidating the number of social benefits and introducing a new benefit for those in poverty. However, the legislation-submitted to parliament in January 2010 - was still pending four months after the program conclusion, whereas the authorities had introduced a new universal transfer regime (Human Development Fund) in the 2010 budget. The delay reflects the cultural and political reluctance to identify and treat the poor differently. And the authorities feared that poverty would be exacerbated, were the universal transfer to be abandoned without a well-designed targeting mechanism. This cultural and political complexity appears to have severely handicapped the influence of the Fund and other international financial institutions - the Asian Development Bank and the World Bank which took an active role in the welfare reform.

\footnotetext{
${ }^{10}$ The Fund put in place a substitute arrangement by having the Medium Term Fiscal Framework (MTFF) adopted in parliament, and having the 2011 budget to be bound by the MTFF under the FRL. This apparently did not prevent the finalized 2011 budget from deviating from the Fund recommendation.
} 


\section{Monetary Policy and Foreign Exchange Market}

\section{Commitment to the flexible exchange rate system was reinforced under the}

program. Although the exchange rate had been allowed to move since late 2008, the inefficient functioning of the market was evident in the rising currency premium in the informal parallel market and the rapid loss of international reserves. The swift implementation of the non-discriminatory auctions of foreign exchange - made possible by the timely provision of MCM TA — normalized the foreign exchange market, facilitating the price discovery and eliminating the informal-market premium. The approval of SBA thus brought about an immediate change in the monetary policy regime from exchange rate to monetary aggregate targeting. Agreement was reiterated in several reviews that, beyond the program horizon, the flexible exchange rate system would provide a shock absorber for Mongolia in the face of the volatility in commodity export prices. ${ }^{11}$

\section{Under the program, monetary policy was adapted to changing circumstance in a} timely manner, leveraging upon the lessons learned from the Asian financial crisis. ${ }^{12}$ Monetary policy was tightened at the outset in support of the exchange rate adjustment, but was soon allowed to respond flexibly to the need of supporting activity and warding off inflation pressure. The initial rate hikeincrease by 425 basis points to signal a regime change and limit the capital outflow_-began to be reversed within three months as soon as the exchange rate stabilized and remonetization progressed. The policy rate was since lowered in a measured pace, until economic recovery and the accompanying build-up of inflation pressure led to a tightening bias near the end of the program, involving an increase in the policy rate and a sizable nominal appreciation.

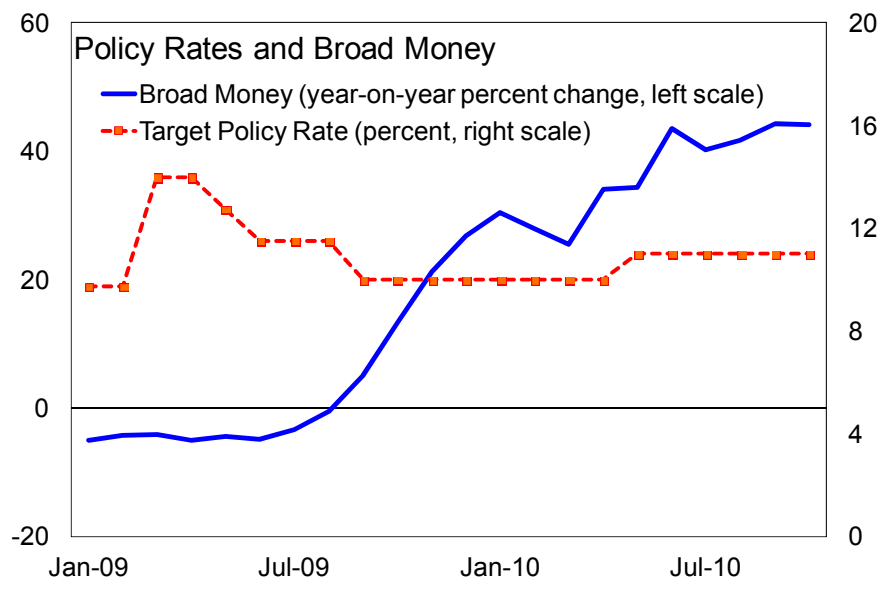

\section{The conduct of monetary policy shifted from a passive to a proactive mode} during the program. The economically needed real exchange rate adjustments (often appreciation) were achieved via nominal exchange rate adjustments, whereas in pre-crisis years the necessary real exchange rate appreciation used to be realized by a run-away

\footnotetext{
${ }^{11}$ For the importance of commodity prices in the equilibrium exchange rate, see "Commodity Currencies" (YuChin Chen and Kenneth Rogoff, Journal International Economics 2003), and IMF OP 261, Exchange Rate Assessments: CGER Methodologies.

${ }^{12}$ On the difficult balance between stabilizing the exchange rate and supporting activity, see IMF OP178, IMFSupported Programs in Indonesia, Korea, and Thailand: A Preliminary Assessment, 1999.
} 
inflation. The auction system for central-bank bills were improved, including by introducing a new auction system for 7-day central-bank bills. Inflation targeting was discussed as the desirable framework of monetary policy beyond the program horizon. However, vigilant effort will be required to sustain this progress, not least because the possible return of fiscal pro-cyclicality can severely constrain the effectiveness of monetary policy and lead to a regress in the policy conduct.

\section{E. Financial Sector}

\section{The primary goal of the program for the financial sector was to restore} confidence in the banking system. Although Mongolia was not directly impacted by the global financial crisis, the pre-crisis credit boom had weakened the balance sheets and confidence in the banking system. The deposit guarantee system was improved (a prior action), and the insolvent Anod Bank and Zoos Bank were eventually placed under receivership by late 2009. The program measures forestalled a system-wide spillover of the stresses in the two banks, despite pervasive weakness in many less affected banks.

\section{Complemented by TA from the Fund and World Bank, the program somewhat} accelerated the legislative progress with bank supervision and restructuring. A revised banking law was approved in parliament in January 2010, introducing consolidated supervision and improving the resolution framework. The Bank of Mongolia later (August) issued several new regulations under the revised law, which increased provisioning for restructured loans and tightened the supervision of related-party loans. The authorities in parallel submitted to parliament the Empowering the Banking Sector and Capital Support Program, which would legislate a comprehensive restructuring framework that was fair to both banks and taxpayers. Awaiting the passage of the Program, the authorities were developing, with MCM TA, bank-by-bank implementation plans which would help address a substantial deficiency of capital in some banks.

\section{This de jure progress in the financial sector reform has yet to be matched by de} facto progress. Although the immediate financial-sector pressure was managed successfully under the program, several long-standing vulnerabilities were left to be addressed by future progress in bank restructuring. Enforcement of bank regulation was not sufficiently strong, with regulatory forbearance being viewed too widespread. The passage of the Banking Sector and Capital Support Program in parliament was anything but assured four months after the program conclusion, despite its urgency due to the possible overstatement of capital adequacy in some systemic banks. ${ }^{13}$ Continued progress with follow-up legislation and implementation would be critical for limiting the future macro-financial vulnerability, which could be magnified under a commodity boom or strong economic development.

\footnotetext{
${ }^{13}$ The Financial Sector Assessment Program (in November 2010) recommended the authorities to monitor the loan quality of systemic exposures in the banking system and to ensure adequate provision for them.
} 


\section{F. Future Challenges}

37. Despite concrete progress made in structural areas, the program failed to secure a durable pre-commitment to implement and sustain reforms achieved under the program, thereby leaving several sources of vulnerability at loose. A full and strict adherence to the FRL is not assured, given the 2011 budget deficits that rose significantly above the levels discussed during the program. A comprehensive social welfare reform is pending in parliament for nearly a year, with unclear prospects for passage given the sociopolitical background. Restructuring of some banks has yet to proceed, pending the legislation of a comprehensive bank restructuring program.

38. Strong implementation of these reforms will be essential to precluding the return of boom-bust cycles driven by global commodity price volatility. The forthcoming economic boom driven by the mineral sector adds to the urgency of completing or locking in reforms initiated under the SBA, in order to maximize the benefit from the resource-driven boom. Medium-term oriented macroeconomic policy is needed to avoid boom-bust cycles in the near term and to avoid the Dutch disease over a longer term. Critical areas are: (i) to lock in fiscal prudence including by fully implementing the FRL; (ii) to maintain the improved monetary policy conduct by keeping inflation pressure at bay and maintaining exchange rate flexibility; (iii) to strengthen the banking system through prudential regulation and supervision; and (iv) to improve the efficiency of social welfare program.

\section{The Fund should facilitate the fruition of these reforms initiated under the SBA} through constructive policy consultations. As experienced during the latter part of the program when the need for Fund financing dissipated, candid policy consultations between the Fund and the authorities can contribute to the authorities' galvanizing political support and pushing forward challenging reforms. As a catalyzing advisor, the Fund should contribute to the authorities' navigating through rapid socio-economic transformation to accompany the resource-driven boom.

\section{Conclusion}

40. The 18-month program succeeded in achieving its main objectives. The sizable and front-loaded financing helped Mongolia to lessen the pain of adjusting to the worst of the global financial crisis. In the process, several structural reforms were pushed forward, which would reduce the pro-cyclicality of economic policies and thereby increase the resilience to the volatility in mineral exports. Though incomplete, tangible progresses made in structural areas should provide stepping stones for further improvement in policy framework.

\section{The success was due to the flexible design and implementation of the program.}

To meet the urgent and sizable financing need of the country, the program provided a prompt SBA financing with streamlined conditionality for a fledgling emerging market economy (still eligible for PRGF). Quantitative targets focused on capping the financing gap, and structural benchmarks were limited to the most germane sources of macroeconomic 
vulnerability. Focused conditionality, combined with flexible implementation and extensive outreach effort, helped strengthen the program ownership.

42. The program, however, failed to secure a proactive commitment to lock in reforms achieved under the program, and the Fund should assist the authorities to complete reforms initiated under the SBA. Particularly important areas are a strict adherence to the FRL, social welfare reform, and a comprehensive bank restructuring. Strong implementation of these reforms will be essential to precluding the return of boom-bust cycles driven by global commodity price volatility, and the Fund's constructive policy consultations should contribute to the authorities' effort to attain lasting macro-financial stability. 
Table 1. Progress with Structural Benchmarks

\begin{abstract}
Structural Benchmarks
Revising relevant laws to require Erdenet to pay taxes in Togrog.

Establishment of screen-based system for inter-bank foreign exchange transactions.

Announcement of a resolution plan for Anod bank based on the diagnostic assessment of the external auditor.
\end{abstract}

A comprehensive review of transfer programs resulting in a revision of the relevant laws to streamline transfer programs and safeguard the social safety.

Submission to the parliament of a revised banking law and other pertinent laws and legislations that include: (i) strengthened prompt corrective action clauses including an increase in penalties for noncompliance; (ii) requiring consolidated supervision; (iii) an improved bank resolution framework that more clearly defines the roles of the conservator and liquidator; (iv) legal protection for bank and nonbank supervisors; (v) a more clear definition of "group of connected parties;" and (vi) reinforced prudential supervision requirements.

Pass a 2010 budget consistent with the IMF supported Stand-By Arrangement.

The submission to parliament and parliamentary passage of Fiscal Responsibility Law consistent with recommendations of Fund TA.

Pass a comprehensive social transfer reform that saves money and protects the poor through better targeting.

\section{Status}

Required by June 30, 2009.

Completed on July 9, 2009.

Required by June 30, 2009. Not completed. Benchmark not reinstated in the second review because it was no longer macrocritical - the central bank will continue to use auctions.

Required by June 30, 2009.

Delayed to end-October.

Complete on November 30, 2009.

Anod bank was put into receivership.

Required by June 30, 2009.

Completed late June 2009, reform plan approved by Cabinet level Working Group.

Required by June 30, 2009.

Completed on July 24, 2009.

Required by December 1, 2009.

Completed on November 27, 2009.

Required by December 31, 2009.

Delayed to June 15, 2010.

Completed on June 24, 2010

Required by December 1, 2009.

Delayed to February 1, 2010.

Delayed to June 15, 2010.

Delayed to November, 2010. 
Table 2. Performance Criteria: Targets and Outcomes

\begin{tabular}{|c|c|c|c|c|c|c|c|c|c|c|c|c|c|c|c|c|}
\hline \multirow[b]{2}{*}{ Performance criteria } & \multicolumn{2}{|c|}{$4 / 30 / 2009$} & \multicolumn{2}{|c|}{$6 / 30 / 2009$} & \multicolumn{3}{|c|}{$9 / 30 / 2009$} & \multicolumn{3}{|c|}{$12 / 31 / 2009$} & \multicolumn{3}{|c|}{$3 / 31 / 2010$} & \multicolumn{3}{|c|}{$6 / 30 / 2010$} \\
\hline & Prog. & Outcome & Prog. & Outcome & Prog. & Rev. ${ }^{1 /}$ & Outcome & Prog. & $\operatorname{Rev}^{2 \prime}$ & Outcome & Prog. & Rev. $^{3 /}$ & Outcome & Prog. & Rev. $^{3 /}$ & Outcome \\
\hline $\begin{array}{l}\text { Net international reserves (NIR) } \\
\text { of the Bank of Mongolia (BOM) } \\
\text { (floor, eop stock, in million US\$). }\end{array}$ & 335 & 441 & 315 & 475 & 455 & 537 & 763 & 575 & 798 & 923 & 600 & 809 & 957 & 535 & 776 & 983 \\
\hline $\begin{array}{l}\text { Net domestic asset (NDA) of the } \\
\text { BOM (ceiling, eop stock, in billion } \\
\text { togrog). }\end{array}$ & -32 & -287 & 14 & -243 & -195 & -302 & -618 & -332 & -542 & -728 & -331 & -645 & -793 & -224 & -477 & -796 \\
\hline $\begin{array}{l}\text { Net credit to government (NCG) } \\
\text { (ceiling, cumulative from the } \\
\text { beginning of the fiscal year, in } \\
\text { billion togrog). }\end{array}$ & 105 & 82 & 156 & -19 & 72 & -69 & -150 & 81 & 58 & -17 & 87 & 220 & 16 & 227 & 270 & 130 \\
\hline $\begin{array}{l}\text { New nonconcessional external } \\
\text { debt maturing in one year or } \\
\text { more, contracted or guaranteed } \\
\text { by the government or the BOM } \\
\text { (ceiling, eop stock since April } \\
2009 \text {, in million US\$). }\end{array}$ & 200 & 0 & 200 & 100 & 200 & 200 & 100 & 200 & 200 & 100 & 200 & 200 & 100 & 200 & 200 & 100 \\
\hline $\begin{array}{l}\text { New nonconcessional external } \\
\text { debt maturing in less than one } \\
\text { year, contracted or guaranteed } \\
\text { by the government or the BOM } \\
\text { (ceiling, eop stock since April } \\
2009 \text {, in million US\$). }\end{array}$ & 0 & 0 & 0 & 0 & 0 & 0 & 0 & 0 & 0 & 0 & 0 & 0 & 0 & 0 & 0 & 0 \\
\hline $\begin{array}{l}\text { Accumulation of new external } \\
\text { payment arrears (ceiling, eop, in } \\
\text { million US\$). }\end{array}$ & 0 & 0 & 0 & 0 & 0 & 0 & 0 & 0 & 0 & 0 & 0 & 0 & 0 & 0 & 0 & 0 \\
\hline $\begin{array}{l}\text { Accumulation of domestic } \\
\text { payment arrears (ceiling, eop, in } \\
\text { billion togrog). }\end{array}$ & 0 & $\ldots$ & 0 & 0 & 0 & 0 & 0 & 0 & 0 & 0 & 0 & 0 & 0 & 0 & 0 & 0 \\
\hline \multicolumn{17}{|l|}{ Indicative targets } \\
\hline $\begin{array}{l}\text { General government fiscal } \\
\text { deficit }^{4 /} \text { (ceiling, cumulative since } \\
\text { the beginning of fiscal year, in } \\
\text { billion togrog). }\end{array}$ & 250 & 144 & 325 & 248 & 290 & 315 & 333 & 380 & 416 & 343 & 125 & 220 & 9 & 200 & 270 & 68 \\
\hline
\end{tabular}

$1 /$ Revised on the second review.

2/ Revised on the third review.

4/ Excludes bank restructuring cost. 
Figure 1. Macroeconomic Developments

Main Message: The economy was severely hit by the crisis, but rebounded strongly.

The sharp collapse of commodity prices, notably for copper, triggered Mongolia's economic crisis in 2008 and 2009, with the quick recovery in 2010.

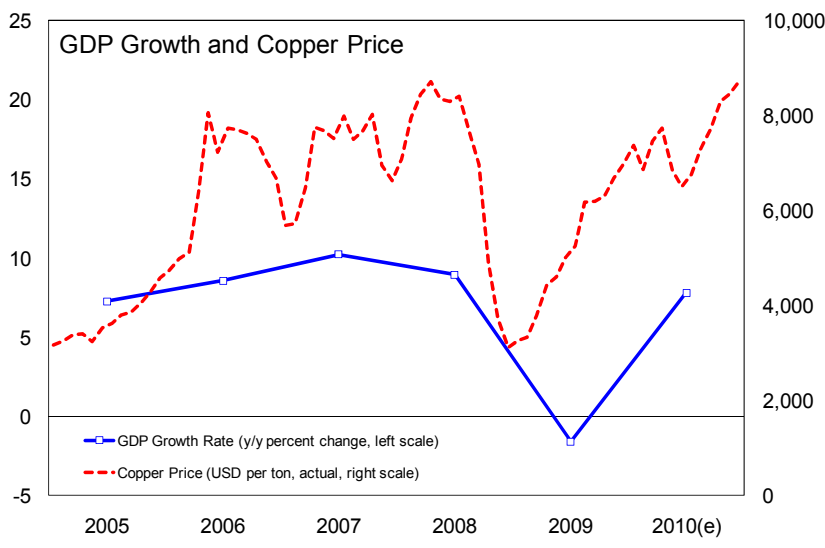

The resulting mineral export slowdown led to the current account deficit, while FDI broadly remained stable.

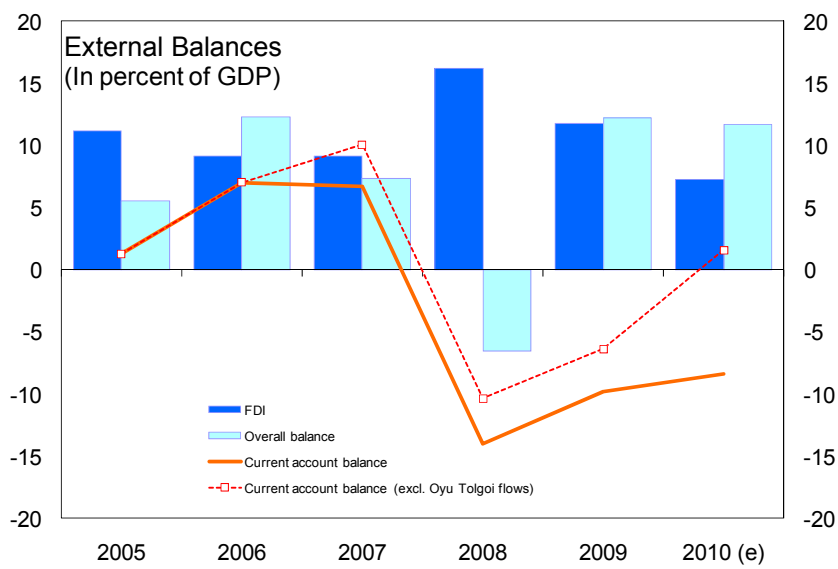

Inflation spiked and the real interest rate turned negative before the crisis. Inflation then fell rapidly with the economic contraction.

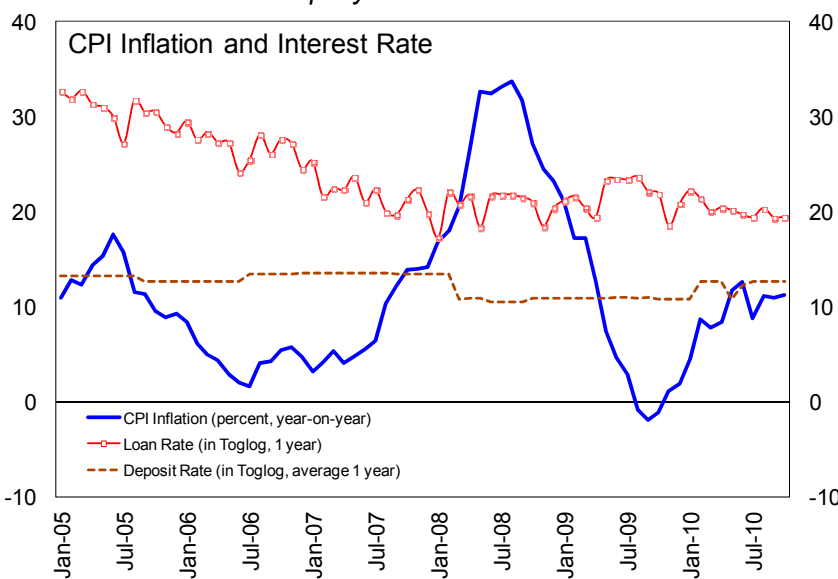

Sources: Mongolian authorities; and IMF staff estimates.
The resulting decline of revenue, especially for mining, weakened key fiscal indicators, and...

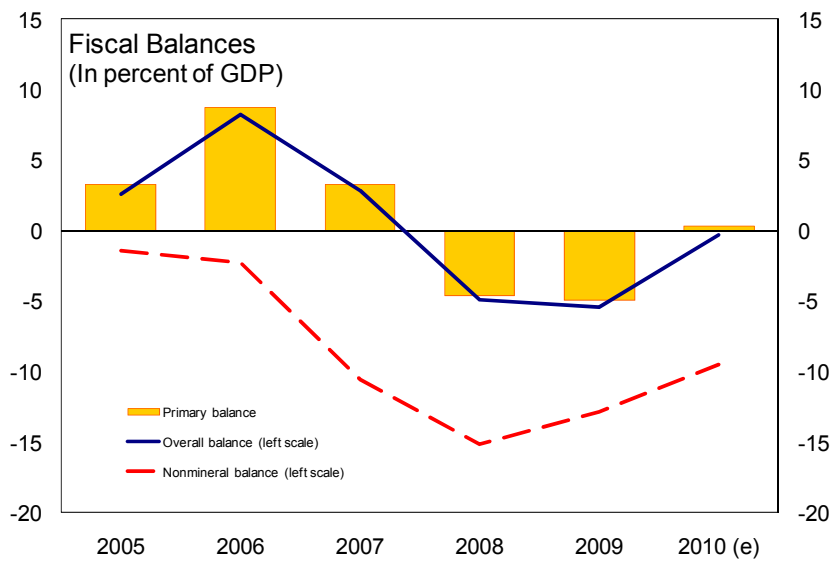

In the midst of the crisis (since late 2008), the exchange rate depreciated and international reserves dropped sharply.

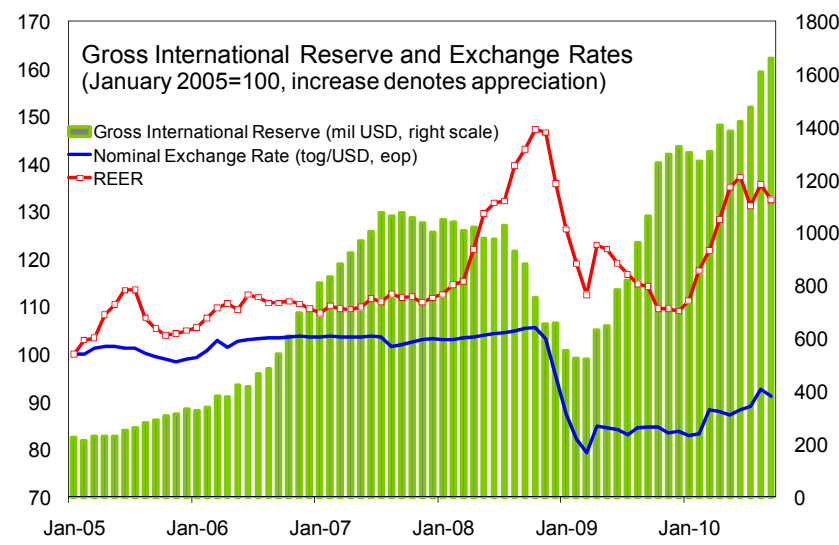

Banking sector stress peaked in late 2009, followed by a steady improvement in bank balance sheets.

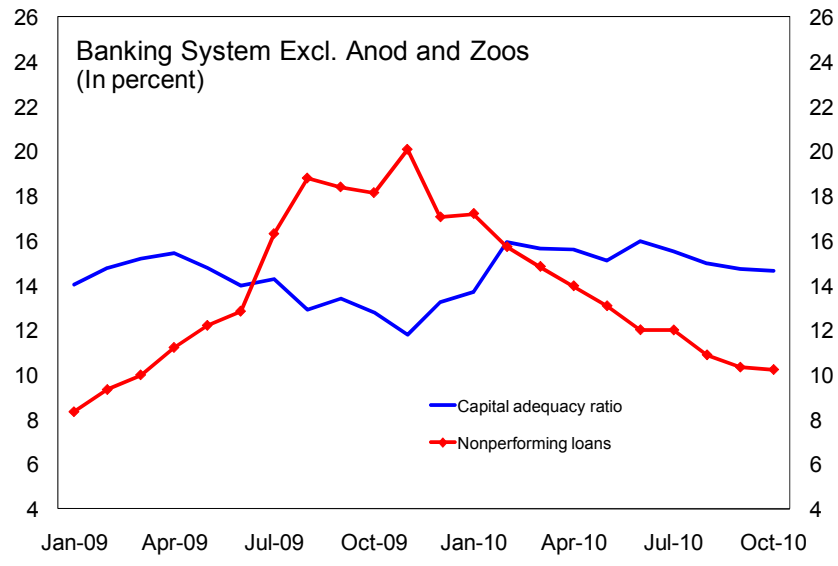


Figure 2. Comparison of Macroeconomic Performance with Other Program Countries (Median) 1/
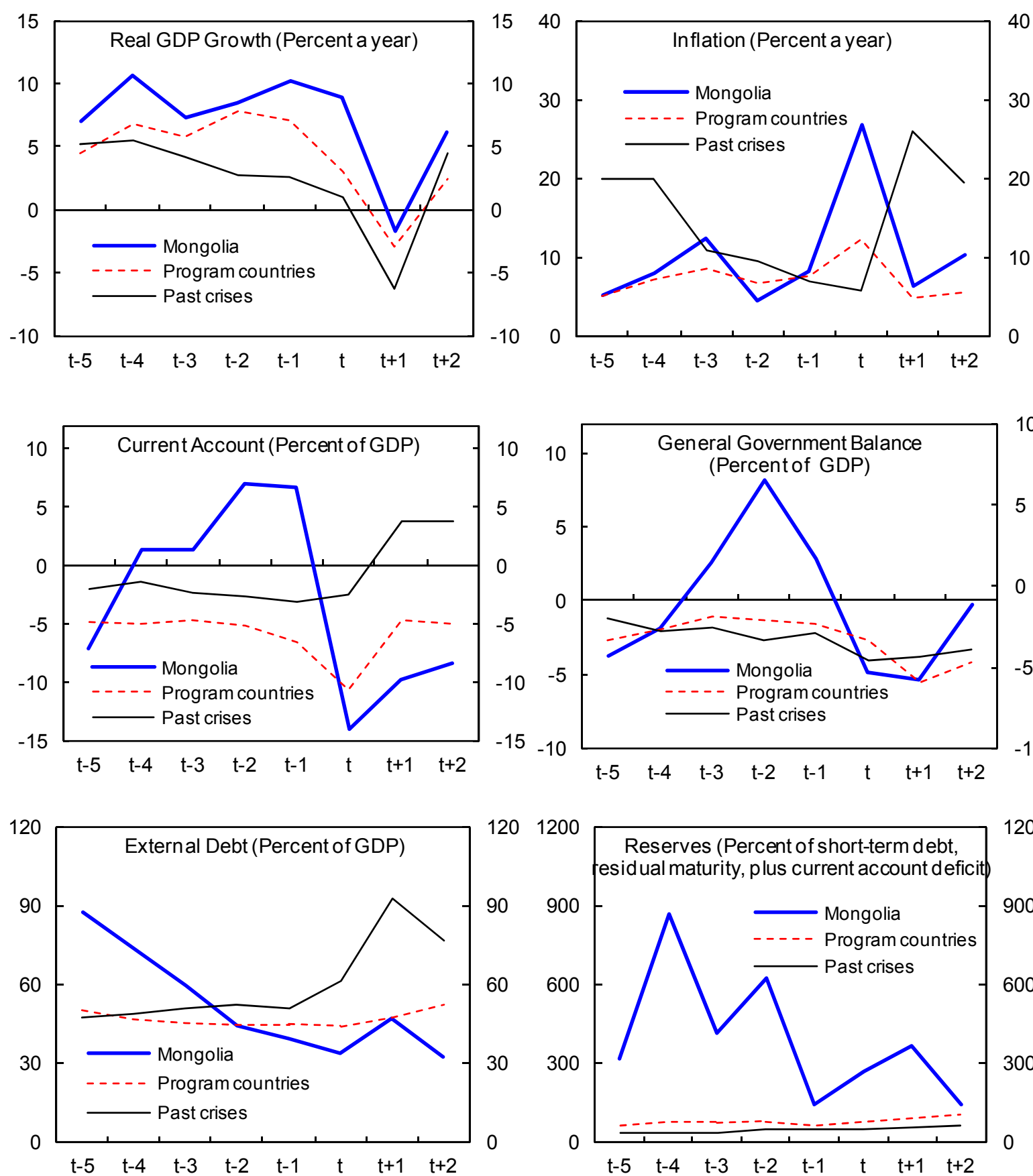

120
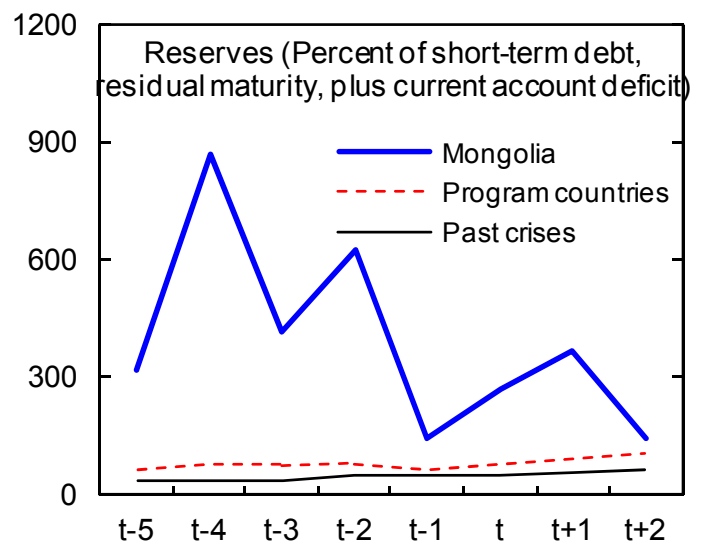

1200

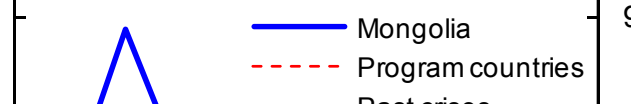

Sources: IMF, World Economic Outlook; and IMF staff calculations.

$1 / t$ is 2008 for current program countries. Data for $t+2$ reflects October 2010 WEO 
Figure 3. Program Projections, Targets, and Outcomes
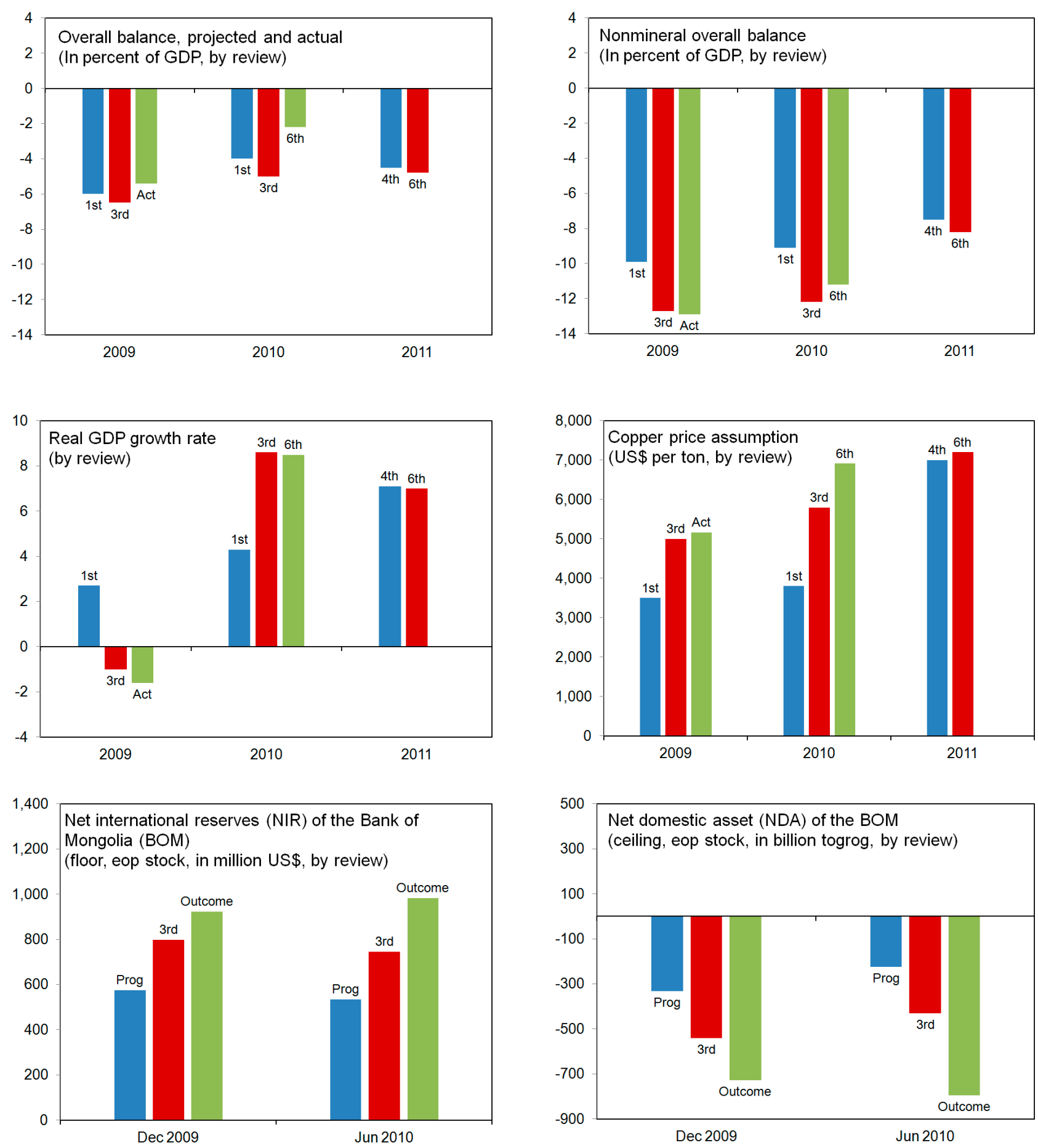

Sources: Mongolian authorities; and IMF staff estimates. 